\title{
The Effectiveness of the Story Assistance Program to the Moral Aspects of ADHD Children in Kindergarten
}

\author{
Nur Cholimah ${ }^{1}$, Suparno Suparno ${ }^{2}$ \\ \{nurcholimah@uny.ac.id $\left.{ }^{1}\right\}$ \\ Universitas Negeri Yogyakarta, Early Childhood Education Department, Yogyakarta, Indonesia ${ }^{1,2}$
}

\begin{abstract}
The purpose of this study was to see how effective the story assistance program, which was carried out on 5-year-old children who had Attention Deficit Hyperactivity Disorders or ADHD, on the moral aspects. This program was carried out for 2 weeks using the SSR method. One kindergarten child who experienced ADHD was observed in one moral aspect, namely respect, seen from the affective, cognitive, and psychomotor components. The child was given an intervention for 2 weeks at school with stimulation with something that makes empathy, and then he was read a story and given a habituation to greet others. The initial observations indicated that the child had not been able to show empathy, did not want to hear let alone ask questions, and when given examples of greeting, he did not see and his views were not focused. Every day, the child was stimulated with something that creates a sense of empathy, told a story and habituated to greet for 10 times. The next step was intervention. In the first week, the result for empathy was 50\%, for listening to stories was 55\%, and for greeting others was $50 \%$. In week 2 there was a $65 \%$ increase in empathy, $85 \%$ in listening to stories, and $80 \%$ in greeting habits. The results show empathy or affective feelings for children takes more time, especially for ADHD children. The program of Moral Assistance with stories was proven to be effective for improving the moral aspects of cognitive morals as a basis for reasoning.
\end{abstract}

Keywords: ADHD children, Moral affective, Cognitive, Psychomotor

\section{Introduction}

Early childhood / preschool is the most important moment of human life [2]. This is because at that age, the development of intelligence increase from $50 \%$ to $80 \%$, and children begin to be sensitive to accept various efforts to develop their full potential [3]. This means that the early age ranges from 0-6 years old is a foundation for individual development at a later stage, as well as a foundation for the formation of behavior through habituation and practice that must be implanted.

One of the problems is that not all children can get through the process of development properly. Various developmental problems manifested in children's behavior in kindergarten in Yogyakarta, namely aggressiveness, anxiety, temper tantrums, concentrating difficulty, stuttering or communicating difficulty, avoidant personality, enuresis and encopresis, lying, crying excessive, dependent, timid, and excessive fear. Related to the above, the observations of kindergarten educators in several kindergartens in Yogyakarta show that in solving various problems that arise when children interact, children aged 4-6 years use aggressive strategies as much as $50 \%$, passive strategies $48 \%$ and $2 \%$ other strategies. 
Lately, there are many teachers or parents find difficulty in teaching their students or children. The difficulty is due to the lack of understanding and skill of teaching. However, the problems are not only from the teachers or parents but also from the students or children

Based on an observation in a kindergarten, there was a 5 years old child with the initial BR who was always tireless and did excessive activities. The child often became easily impulsive, often irritated other children, often failed to complete activities that have been started, had short attention spans, always moved his body or head continuously, often lacked of focus and was easily diverted, sometimes became frustrated if his desires were not fulfilled, often blew up resentment with explosive and unexpected behavior. Those facts indicated attention deficit hyperactivity disorders or ADHD.

ADHD is a disorder indicated by persistent pattern of lack of focus, hyperactivity, and impulsiveness [1]. Children with ADHD show multiply difficulties in daily functions, including in the domains of academic, social, family, and behavior.

Children behaviors are various. Some of them are active and excited in following the lesson. However, there are some others who are passive, hard to be managed and cannot stay still, and have no will to pay attention to the teacher. This kind of children usually experience hyperkinetic disorder, which is commonly called hyperactive. Hyperactive children are those who experience problem with their focus. Teachers usually find difficulties in managing and teaching children with this condition because, beside the condition that the children can not be calm, hyperactive children also often disturb others and have difficulty in understanding what the teachers teach.

Moreover, hyperactive children usually have insufficient moral values. Therefore, it requires approaches to help hyperactive children maximizing their moral values. Therefore, the researcher conducted research on the effectiveness of the activity program to help the child with the initials BR so that the development of the child's moral values could increase.

\section{Literature Review}

Although there are some previous studies relating empathy with children's social behavior with peers, none has yet revealed how empathy exists in ADHD children and how to improve it. These findings indicate that a brief BPT managed group program for a variety of participants in a special outpatient management produces improvements in functional disorders comparable to those produced in controlled studies, as well as increased self-confidence in parenting [10]. Thus, the purpose of this study is to improve the moral aspects of respect with 3 components (a) affective moral empathy, (b) cognitive moral in listening to stories, and (c) Psychomotor morals with greeting habits. The ADHD assistance program by children's story is expected to be effective in improving moral aspects, namely respect.

Telling folk tales means teaching survival and socialization as well as reflecting the moral of the previous generation [12]. Moreover, telling story shows significant contribution to children's learning and development related to imagination, concept of shaping and thinking, and out of themselves, socially, telling story can be important part of early childhood education. 


\section{Method}

\subsection{Participant}

Participant in this study was a 5-year-old exceptional kindergarten child, with the initials BR. The child was always tireless and did excessive activities, often became easily impulsive, often irritated other children, often failed to complete activities that have been started, had short attention spans, always moved his body or head continuously, often lacked of focus and was easily diverted, sometimes became frustrated if his desires were not fulfilled, often blew up resentment with explosive and unexpected behavior. Those facts indicated attention deficit hyperactivity disorders or ADHD.

\subsection{Action and Procedure}

Research is a way to figure out and find answer of questions or problems systematically by using scientific methods. The method used in this research was experiment. Therefore, the researcher directly experimented to find the causality or effects among variables. The research design was Single Subject Research (SSR). SSR is experimental research conducted to figure out how much a treatment given continuously to the subject affects [11].

In Single Subject Research (SSR), basically, the subjects are treated in a state without treatment / intervention and with treatment / intervention alternately, and the target behavior is measured repeatedly with certain time periods such as weekly, daily, or hourly. Before conducting treatment or intervention, researchers first determine the target behavior (target behavior) to be changed. When in a non-treatment situation, the subject is given the symbol "A" and when in the treatment, the subject is given the symbol "B". After being able to determine the target behavior, the researcher then planed the behavior modification. According to the opinion of Sunanto, Takeuchi \& Nakata [11], which state that determining the behavior to be changed in a modification program, is the earliest and most important activity. In terms of single subject research, the behavior to be changed is called target behavior. In the aspect of research, the target behavior is also known as the bound variable. Experimentally, to change behavior that is not adaptive, the habits that are not adaptive are weakened and eliminated, and adaptive behavior is generated and confirmed.

The research design used was a reversal design (A-B-A-B) because the design showed a stronger control over the independent variables compared to the A-B-A design. Therefore, the internal validity was increased so that the results of research showed functional relationships between dependent and independent variables were more convincing. By comparing the two baseline conditions before and after the intervention the effect of the intervention is more convincing. The independent variable used is PECS (Picture Exchange Communication System) method, while the dependent variable used is aggressive behavior in ADHD children. The steps taken in the design of A-B-A-B include 4 stages, namely: 1). Baseline 1 (A1), the average occurrence of behavior in a certain period after being measured through observation. At baseline 1 (A1), the moral aspect measurement of ADHD children was carried out in the initial conditions in a natural state before being given an intervention by the PECS (Picture Exchange Communication System) method. 2) Intervention 1 (B1), a condition of giving treatment repeatedly to reach a clear trend and level. The treatment will be given after the data becomes stable at baseline 1 (A1), the intervention given is learning using the PECS method (Picture Exchange Communication System). 3). Baseline 2 (A2), a condition of ADHD children after being given an intervention. In this observation, the measurements were taken using frequency 
and seen from the number of moral aspects, namely affective in the form of empathy, cognitive in listening to stories and psychomotor with habituation of greetings seen from the quality that emerged. 4) Intervention 2 (B2) Interventions at this stage were carried out the same way as intervention 1 (B1), which was learning using the PECS (Picture Exchange Communication System) method, in which the baseline used was baseline 2 (A2). 5) Target Behavior, the behavior to be changed, the behavior which is expected to increase or decrease (disappear) depending on the purpose of the research. Behavior targets in behavior modification are thoughts or actions that can be recorded and measured. The target behavior in this research was ADHD behavior. To collect these data, the researchers used direct and indirect observation by recording and interviewing the teachers. Meanwhile, the calculation of the target behavior was done quantitatively.

\section{Result and Discussion}

\subsection{Result}

The results of observations before the intervention by the program of reading stories and habituation, the focus of observation was on the moral development of BR, showed that BR did not make eye contact when spoken to, and he lacked of focus and often did not listen. Therefore, for 2 weeks the intervention was carried out with a program of reading stories and habituation on moral aspects. Indicators of moral development that will be observed can be read in Table 1 . The moral aspects observed were courtesy or respect consisting of 3 components: affective in the form of empathy which can respect softness with touch, moral cognitive in the form of listening to stories, and psychomotor by greeting courtesy with focused eyes.

Table 1. Indicator of respect

\begin{tabular}{|c|c|c|c|c|}
\hline \multirow{2}{*}{$\begin{array}{l}\text { Indicator of Respect / } \\
\text { Politeness }\end{array}$} & \multicolumn{4}{|c|}{ SCORE } \\
\hline & 1 & 2 & 3 & 4 \\
\hline Responding softness with a & If child has not & If the child has & If the child has & If the child has \\
\hline touch & responded yet & $\begin{array}{l}\text { begun to } \\
\text { respond by } \\
\text { touch through } \\
\text { guidance }\end{array}$ & $\begin{array}{l}\text { responded to } \\
\text { touch without } \\
\text { being guided }\end{array}$ & $\begin{array}{l}\text { responded with } \\
\text { a soft touch }\end{array}$ \\
\hline $\begin{array}{l}\text { Listening to Stories and } \\
\text { Answering Question }\end{array}$ & $\begin{array}{l}\text { if the child has } \\
\text { not answered }\end{array}$ & $\begin{array}{lr}\text { If the child } \\
\text { listens } \\
\text { stories } \\
\text { guidance }\end{array}$ & $\begin{array}{l}\text { If the child } \\
\text { listens to the } \\
\text { stories }\end{array}$ & $\begin{array}{lr}\text { If the child } \\
\text { listens } \\
\text { answers } \\
\text { questions }\end{array}$ \\
\hline $\begin{array}{l}\text { Greet with polite language } \\
\text { and eyes focus on seeing }\end{array}$ & $\begin{array}{l}\text { If the child has } \\
\text { not greet }\end{array}$ & $\begin{array}{l}\text { If the child } \\
\text { greets with } \\
\text { guidance }\end{array}$ & $\begin{array}{ll}\text { If the child } \\
\text { greets with } \\
\text { polite } \\
\text { language }\end{array}$ & $\begin{array}{l}\text { If the child } \\
\text { greets politely } \\
\text { with eyes focus } \\
\text { on seeing }\end{array}$ \\
\hline
\end{tabular}

The results of 2 weeks observation at baseline A1 showed that the 5-year-old child with the initials BR has not shown tenderness even tend to be frontal, did not want to hear stories let alone ask questions and say hello. Then he was given treatment by intervening for 1 week repeatedly. The child was touched gently, read a story book with 10 children's story titles to be chosen every day, and trained to greet others. The results of the B1 intervention, which was 
carried out during the 5-day mentoring program by reading stories by selecting the 10 stories that have been provided, showed improvement as shown in (Table 2). The increase was in building empathy by responding to softness called moral affective with a score of 10 or $50 \%$ of the expected score. On cognitive morals, with stories being read and children listening, the score was 11 or $55 \%$, and the score of psychomotor moral / habitual behavior through greeting was 10 or $50 \%$.

The results of B2 interventions carried out over 5 days with repetitive program activities, on the moral aspect of respect, showed the results as listed in (Table 3). There was an increase in scores in building empathy by responding to gentleness: affective morals with a score of 13 or $65 \%$ of the expected score, cognitive morals with a score of 17 or $80 \%$, and psychomotor moral / habitual behavior obtained a score of 16 or $80 \%$. In stage 5, the target behavior (behavior that was changed, i.e., the moral aspect of respect), a 5-year-old BR was proven to increase with repeated storybook mentoring activities as shown in table 4 and 5.

Table 2. Recapitulation results week 1 of ADHD child moral improvement of respect

\begin{tabular}{ll}
\hline Moral Improvement (Respect) & Total Score \\
\hline Responding to Softness by touch & $10 / 20(50 \%)$ \\
Listening to stories and answering question & $11 / 20(55 \%)$ \\
Greeting politely with focused eyes & $10 / 20(50 \%)$ \\
\hline Total Score 31/60 (52\%) & \\
\hline
\end{tabular}

Table 3. Recapitulation results week 2 of ADHD child moral improvement of respect

\begin{tabular}{lc}
\hline Moral Improvement (Respect) & Total Score \\
\hline Responding to Softness by touch & $13 / 20(65 \%)$ \\
Listening to stories and answering question & $17 / 20(85 \%)$ \\
Greeting politely with focused eyes & $16 / 20(80 \%)$ \\
\hline Total Score 46/60 (77\%) & \\
\hline
\end{tabular}

Table 4. Recapitulation results of Week I observation of the moral development of ADHD children

\begin{tabular}{|c|c|c|c|c|c|c|c|c|}
\hline \multirow{3}{*}{$\begin{array}{c}\text { Week } \\
\text { Week } \\
\text { I }\end{array}$} & \multirow{2}{*}{\multicolumn{2}{|c|}{ Indicator Respect / Polite }} & \multicolumn{5}{|c|}{ EVALUATION } & \multirow{2}{*}{$\begin{array}{l}\text { Total } \\
\text { Score }\end{array}$} \\
\hline & & & \multirow{2}{*}{$\begin{array}{c}\text { Day } \\
\mathbf{1} \\
1\end{array}$} & \multirow{2}{*}{$\begin{array}{c}\text { Day } \\
\mathbf{2} \\
1\end{array}$} & \multirow{2}{*}{$\begin{array}{c}\text { Day } \\
\mathbf{3} \\
2\end{array}$} & \multirow{2}{*}{$\begin{array}{c}\text { Day } \\
\mathbf{4} \\
3\end{array}$} & \multirow{2}{*}{$\begin{array}{c}\text { Day } \\
\mathbf{5} \\
3\end{array}$} & \\
\hline & $\begin{array}{l}\text { Building empathy and } \\
\text { feelings (Affective) }\end{array}$ & $\begin{array}{ll}\text { Responding } & \text { Softness } \\
\text { with a touch } & \end{array}$ & & & & & & $\begin{array}{l}10 / 20 \\
50 \%\end{array}$ \\
\hline & $\begin{array}{l}\text { Introducing \& } \\
\text { Understanding Story } \\
\text { Books (Cognitive) }\end{array}$ & $\begin{array}{l}\text { Listening to stories and } \\
\text { answering questions }\end{array}$ & 1 & 2 & 2 & 2 & 3 & $\begin{array}{c}11 / 20 \\
55 \%\end{array}$ \\
\hline & Habituation & $\begin{array}{l}\text { greeting politely with } \\
\text { eyes focus on seeing }\end{array}$ & 1 & 2 & 2 & 3 & 2 & $\begin{array}{l}10 / 20 \\
50 \%\end{array}$ \\
\hline & & & 3 & 5 & 6 & 8 & 8 & $\begin{array}{l}31 / 60 \\
51 \%\end{array}$ \\
\hline
\end{tabular}


Table 5. Recapitulation results of Week II observation of the moral development of ADHD children

\begin{tabular}{|c|c|c|c|c|c|c|c|c|}
\hline \multirow[b]{2}{*}{ Week } & \multirow[b]{2}{*}{ Program } & \multirow[b]{2}{*}{$\begin{array}{c}\text { Indicator respect / } \\
\text { polite }\end{array}$} & \multicolumn{5}{|c|}{ EVALUATION } & \multirow[b]{2}{*}{$\begin{array}{l}\text { Total } \\
\text { Score }\end{array}$} \\
\hline & & & $\begin{array}{c}\text { Day } \\
1 \\
\end{array}$ & $\begin{array}{c}\text { Day } \\
2\end{array}$ & $\begin{array}{c}\text { Day } \\
\mathbf{3}\end{array}$ & $\begin{array}{c}\text { Day } \\
4\end{array}$ & $\begin{array}{c}\text { Day } \\
5\end{array}$ & \\
\hline \multirow[t]{3}{*}{$\begin{array}{l}\text { Week } \\
\text { II }\end{array}$} & $\begin{array}{l}\text { Building empathy and } \\
\text { feelings (Affective) }\end{array}$ & $\begin{array}{l}\text { Responding } \\
\text { Softness with a } \\
\text { touch }\end{array}$ & 2 & 2 & 3 & 3 & 3 & $\begin{array}{l}13 / 20 \\
65 \%\end{array}$ \\
\hline & $\begin{array}{l}\text { Introducing \& } \\
\text { Understanding Story } \\
\text { Books (Cognitive) }\end{array}$ & $\begin{array}{l}\text { Listening to stories } \\
\text { and answering } \\
\text { questions }\end{array}$ & 3 & 3 & 3 & 4 & 4 & $\begin{array}{c}17 \\
85 \%\end{array}$ \\
\hline & Habituation & $\begin{array}{l}\text { greeting politely } \\
\text { with eyes focus on } \\
\text { seeing }\end{array}$ & 3 & 3 & 3 & 4 & 3 & $\begin{array}{c}16 \\
80 \%\end{array}$ \\
\hline
\end{tabular}

Behavior targets in behavior modification are thoughts or actions that can be recorded and measured. The target behavior in this study was an ADHD behavior. During habituation in every day there was a modification in reading books. The child was asked to choose which title he liked, then question and answer. The ten story books provided were selected by the child treated. The researcher monitored whether the child can last at least 5 minutes to listen and focus his eyes in question-and-answer section. As well as when shaking hands or greeting, the child must learn to greet and shake hands with a touch that is not rough but soft with a focused eye. Story assistance effectively changes children to be more respectful or polite to others. Three moral components can be achieved in ADHD children by listening to stories. Storytelling must naturally involve teachers who are very patient. Patient teachers also contribute in making affectionate children. Various techniques of storytelling were applied, sometimes in the morning under the tree, or near the swing, sometimes during the day when other children were asleep, or in the afternoon. Figure 1 shows the effectiveness of story assistance program to the moral aspect of an ADHD child.

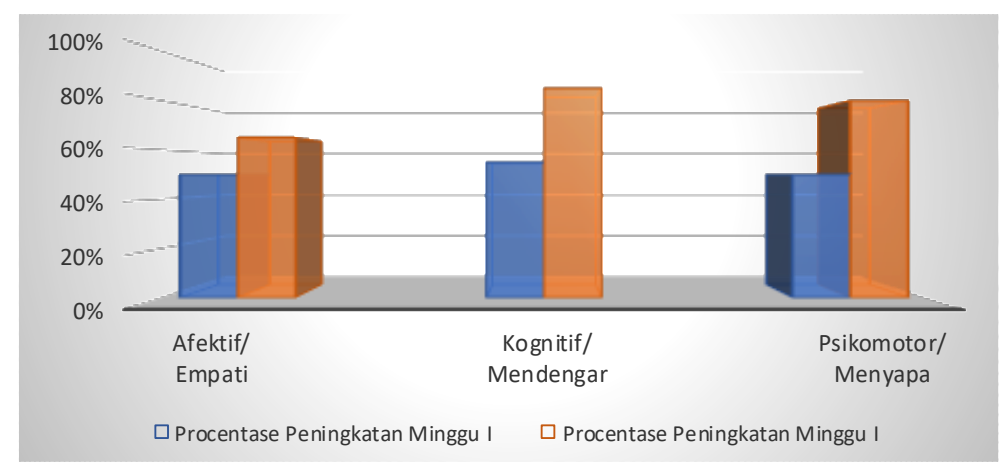

Fig. 1. The effectiveness of story assistance program to the moral aspect of an ADHD child

\subsection{Discussion}

The findings of this study showed that of the 3 moral components, the most difficult progress was in empathy. The results showed that, compared with low empathic peers, more empathic children were reported to exhibit greater pro-social behavior and less aggression and 
social withdrawal [10]. In addition, there is empirical support for a positive relationship between empathy and pro-social behavior, although this association tends to be rather simple. For example, Miller, Eisenberg, Fabes, and Shell found that representative emotional responses (ie, empathy) and moral reasoning were positively related to pro-social behavior toward peers. In fact, the interaction effect is observed in such a way that children who are high both in moral reasoning and emotional responses are most likely to help friends who are in difficulties. Miller, Eisenberg, Fabes, and Shell found that representative emotional responses (i.e., empathy) and moral reasoning were positively related to pro-social behavior toward peers. Empathy has been defined as "affective responses that originate from understanding or understanding of the emotional condition or other conditions". This includes recognizing and experiencing other people's emotional states. Empathy is often accompanied by sympathy or personal distress [8].

Teaching students about moral literacy is essential if the school is to produce productive and responsible citizens. Understanding of moral literacy can play a very vital role in the education system. Moral literacy should not be different from mathematics or literacy reading, because we all as individuals, professionals and citizens need to make many moral decisions throughout life [9].

Moral is a concept that tends to be abstract, considering that moral is talking about values that are abstract concepts. Basically, abstract concepts are not easily understood by children who have a tendency to think about things concretely. Introducing and instilling moral values in children can be done by using the method of storytelling so that children find it easier to understand moral concepts [4]. The findings regarding group discussions about problematic moral situations indicate that it would be useful to provide more opportunities for moral discussion for children in kindergarten classrooms. Cultural beliefs and values influence the teacher's view of children and their pedagogical practices.

Korean traditional education emphasizes greatly on moral education. Korean adults believe that it is their responsibility to know the moral values of their children as early as possible to help them develop moral tendencies, habits and thoughts. They believe that even very young children are able to learn morality without being limited by age and / or stages of cognitive development [5][6]. In contemporary Korean society, the cultural value of moral education continues. Helping children become moral beings is the most important goal for all levels of education. The moral pedagogy of Korean preschool teachers needs to be understood in this Korean context. Piaget claims that young children judge morality based only on results, not intention. They believe that moral norms are unilaterally imposed by adults, and thus children cannot change moral rules from one situation to another [6]. Furthermore, children know that immoral behavior is caused by desires. They consider that troubled behaviors, such as touching someone else without permission, skipping queues and littering, are the result of desire. Lee [5] argues that desire is one of the seven human feelings (joy, anger, sadness, fear, love, hate, and desire). Although children agree that desires are the cause, they conclude that the ultimate goals are different from each other.

The findings in this study indicated that the story assistance program was effective in improving moral aspects which has 3 components: affective, cognitive, and psychomotor. The cognitive moral component was proven to be the highest in influencing moral respect in ADHD children. This was in line with various existing studies that the story method was effective to improve moral aspects. Cognitive moral is a very important asset for a child to be able to do moral reasoning that is useful at all times if he/she is going to make a moral decision in everyday life. Therefore, the child who experienced ADHD disorders, who in the process of intervention was read stories over and over again with patience, was able to respond and over time could focus on listening, and understanding good and bad behaviors. On the habituation of 
psychomotor moral, the child learned to greet others as a form of respect. After being intervened for several days, the child showed improvement. He greeted the teachers with focus. Affective moral is proven to be the one that last longer in ADHD children. It is in line with the previous researches that building affective moral takes stronger effort. Through stories, at least, the child started to speak softly although still need to be reminded. Touching friends or shaking hand softly also still need to be habituated, while communicating with empathy still need longer time.

\section{Conclusion}

In the first week, the result for empathy was $50 \%$, for listening to stories was $55 \%$, and for greeting others was $50 \%$. In week 2 there was a $65 \%$ increase in empathy, $85 \%$ in listening to stories, and $80 \%$ in greeting habits. The results of this study reinforced the previous researches, that to show empathy or affective feelings for children takes more time, especially for ADHD children. The program of Moral Assistance with stories was proven to be effective for improving the moral aspects of cognitive morals as a basis for reasoning. Teachers' patience and persistence in dealing with ADHD children with various strategies in habituating to reading stories, greeting, and responding with tenderness are also the keys to the success of assisting ADHD children to improve morality, in this case, is respect. When a child with ADHD can respect others, it can reduce the image as a child who is difficult to be managed. Otherwise, the child grows into a child who is polite and respectful to others. Training children earlier will be easier than training them when they are grown up.

\section{References}

[1] American Psychiatric Association. (2000). Diagnostic and statistical manual of mental disorders (4th ed., text rev.). Washington, DC: Author.

[2] Berk, L. E. (2012). Development Through Lifespan; Dari Prenatal sampai Remaja (Edisi Kelima). Yogyakarta: Pustaka Pelajar.

[3] Depdiknas. (2008). Penataan Pendidikan Profesional Konselor dan Layanan Bimbingan dan Konseling dalam Jalur Pendidikan Formal. Jakarta: Departemen Pendidikan Nasional.

[4] Hazhira Qudsyi, (2013). Menanamkan Moral Pada Anak Melalui Cerita, Fakultas Psikologi dan Ilmu Sosial Budaya Universitas Islam Indonesia, Psikologika Volume 18 Nomor 1 Tahun 2013.

[5] Lee, D. (1985). Trivial etiquette. (Kim, G., Trans.). Seoul, Korea: Myungmoondang. (Original work published 1775) (in Korean).

[6] Lee, J., Lee, K., Lee, E., Lim, K., Kwak, H., Yoon, M., \& Kim, J. (1997). Moral education bypicture book for children. Seoul, Korea: Dasede (in Korean).

[7] Lee, Y. (1998). Moral education. In Research Institute of Education in Seoul National University (Eds.), The encyclopedia of education (pp. 1045- 1048). Seoul, Korea: Howdonsul (in Korean).

[8] Miller, P. A., Eisenberg, N., Fabes, R. A., \& Shell, R. (1996). Relations of moral reasoning and vicarious emotion to young children's prosocial behavior toward peers and adults. Developmental Psychology, 32, 210-219.

[9] Nancy Tuana, (2007). Conceptualizing moral literacy, Journal of Educational AdministrationVol. 45 No. 4, 2007 pp. 364-378 q Emerald Group Publishing Limited 0957-8234 DOI $10.1108 / 09578230710762409$. 
[10] Richard E. A. Loren, Aaron J. Vaughn, Joshua M. Langberg, Jessica E. M. Cyran, Tara ProanoRaps, Beverly H. Smolyansky, Leanne Tamm and Jeffery N. Epstein (2015). Effects of an 8-Session Behavioral Parent Training Group for Parents of Children with ADHD on Child Impairment and Parenting. Confidence Journal of Attention Disorders. 2015, Vol. 19(2) 158-166.

[11] Sunanto, J. Takeuchi, K, \& Nakata, H (2005). Pengantar Penelitian dengan Subjek Tunggal. Center for Research on InternasionalCooperation of Education Development (CRJCED) Universitas of Tsukuba.

[12] Tadesse Jaleta Jirata, (2011). Children as Interpreters of Culture: Producing Meanings from Folktales in Southern Ethiopia Journal of Folklore Research, Vol. 48, No. 3. 